\title{
OCHRONA PRAW PRACOWNIKÓW W ZAKRESIE ZAANGAŻOWANIA W SPÓŁCE EUROPEJSKIEJ Z SIEDZIBĄ W POLSCE
}

\section{Wstęp}

Prawodawca unijny regulując formę dialogu społecznego, jakim jest zaangażowanie pracowników w spółce europejskiej, po długich pracach legislacyjnych ${ }^{1}$ uchwalił Dyrektywę Rady 2001/86/WE z dnia 8 października 2001 r. uzupełniającą statut spółki europejskiej w odniesieniu do zaangażowania pracowników ${ }^{2}$. Akt ten był dopełnieniem uchwalonego wcześniej Rozporządzenia Rady (WE) Nr 2157/2001 z dnia 8 października 2001 r.

" Dr; e-mail: kamil.golema@gmail.com, https://orcid.org/0000-0001-8302-2886.

1 W zakresie genezy oraz przebiegu prac mających na celu uchwalenie dokumentów statuujących spółkę europejską zob. M. Minas, Spótka europejska w pracach Komisji Wspólnot Europejskich, Kwartalnik Prawa Prywatnego 1996, nr 1, s. 64-70; J. Loranc, Spótka europejska a przepisy polskie, Rejent 2001, nr 6, s. 114-147; A. Szumański, Spółka europejska, Kwartalnik Prawa Prywatnego 1997, nr 2, s. 249-272; A. Szumański, Europejskie prawo spótek, w: Prawo Spółek, red. W. Włodyka, Kraków 1996, s. 711-715; B. Kurcz, M. Kurcz, Spótka Europejska - Societas Europea, Prawo Unii Europejskiej 2002, nr 1, s. 24-27; T. Siemiątkowski, R. Potrzeszcz, Spótka europejska w polskiej typologii spótek handlowych, cz. 1, Przegląd Prawa Handlowego 2005, nr 11, s. 10-15; A. Opalski, Europejskie prawo spótek - zasady prawa europejskiego i ich wptyw na polskie prawo spótek, Warszawa 2010, s. 527-573; E. Felten, Directive 2001/86/EC supplementing the Statute for a European company with regard to the involvement of employees, w: International and European Labour Law, red. E. Ales, M. Bell, O. Deinert, S. Robin-Olivier, Baden Baden 2018, s. 1535-1551; J. Wratny, Fenomen partycypacji pracowniczej w nurcie przemian stosunków pracy, Warszawa 2019, s. 80-84.

2 Dyrektywa Rady 2001/86/WE z dnia 8 października 2001 r. uzupełniająca statut spółki europejskiej w odniesieniu do zaangażowania pracowników, Dz. Urz. UE L 294 z 10.11. 2001, s. 22 (dalej: Dyrektywa 2001/86/WE). 
w sprawie statutu spółki europejskiej (SE) ${ }^{3}$, które formowało ramy nowego podmiotu ponadnarodowego, jakim jest Societas Europea. W kontekście problematyki będącej przedmiotem niniejszego opracowania istotne znaczenie ma punkt 12 preambuły Dyrektywy 2001/86/WE, w myśl którego należy zapewnić przedstawicielom pracowników, działającym $\mathrm{w}$ ramach realizacji założeń tego aktu prawnego, ochronę i gwarancje podobne do tych, jakie przyznaje się przedstawicielom pracowników na podstawie ustawodawstwa i/lub praktyki państwa zatrudnienia, w czasie gdy sprawują swoje funkcje. Nie powinni oni podlegać żadnej dyskryminacji w związku ze zgodnym z prawem wykonywaniem przez nich zadań i powinni oni korzystać z właściwej ochrony na wypadek zwolnienia i innych sankcji. Realizacją tego postulatu jest art. 10 Dyrektywy 2001/86/WE, zgodnie z którym państwa członkowskie zobowiązane są wprowadzić rozwiązania zapewniające ochronę członków specjalnego zespołu negocjacyjnego, członków organu przedstawicielskiego, przedstawicieli pracowników wykonujących funkcje $\mathrm{w}$ ramach procedury informowania pracowników i konsultowania oraz przedstawicieli pracowników w organie nadzorczym lub zarządzającym spółki europejskiej, którzy są pracownikami spółki europejskiej, jej spółek zależnych lub zakładów czy też spółki uczestniczącej. Pełnienie wyżej wymienionych funkcji winno się wiązać z konkretnymi uprawnieniami o charakterze ochronnym, z jednoczesnym uwzględnieniem rozwiązań przyjętych w krajowych porządkach prawnych lub praktyką obowiązującą w państwie zatrudnienia danej osoby. Podkreślić w tym miejscu należy, że celem Dyrektywy 2001/86/WE nie była harmonizacja prawa obowiązującego w państwach członkowskich, dlatego też prawodawca unijny nie zdecydował się na wprowadzenie konkretnego rozwiązania narzuconego krajowym porządkom prawnym. Trafnie jednak zwraca się uwagę, że powyższy sposób regulacji nie sprzyja rozwijaniu dialogu społecznego pomiędzy przedstawicielami pracowników i wypracowaniu jednolitego stanowiska w porozumieniu z pracodawcą ${ }^{4}$.

Istotnym przepisem z punktu widzenia niniejszego opracowania jest także art. 11 Dyrektywy 2001/86/WE, który dotyczy nadużycia procedur.

3 Rozporządzenie Rady (WE) Nr 2157/2001 z dnia 8 października 2001 r. w sprawie statutu spółki europejskiej (SE), Dz. Urz. UE L 294 z 10.11.2001, s. 1 (dalej: Rozporządzenie Nr 2157/2001).

4 A. Giedrewicz-Niewińska, Uczestnictwo pracowników w spółce europejskiej, Warszawa 2015, s. 169. 
Zgodnie z nim państwa członkowskie przyjmują właściwe środki zgodnie z prawem wspólnotowym w celu zapobiegania nadużyciom spółki europejskiej do pozbawienia pracowników prawa do uczestnictwa pracowniczego lub zawieszenia takich praw.

Transpozycja wspomnianej wyżej Dyrektywy 2001/86/WE do polskiego systemu prawnego odbyła się w 2005 r. poprzez uchwalenie ustawy o europejskim zgrupowaniu interesów gospodarczych i spółce europejskiej $^{5}$, a mechanizmy chroniące prawa pracowników w zakresie zaangażowania przejawiają się w różnych aspektach. Ochronie podlega zarówno indywidualny stosunek pracy osób pełniących określone funkcje w zakresie dialogu pomiędzy stroną pracowniczą a pracodawcą, jak również interesy zbiorowe pracowników tworzonej Societas Europea. Także sam proces zaangażowania jest poniekąd chroniony poprzez wprowadzenie do Ustawy o spółce przepisów karnych zakazujących działań uniemożliwiających lub utrudniających zaangażowanie pracowników.

Podnieść należy, iż przy wdrażaniu Dyrektywy 2001/86/WE polski ustawodawca popełnił błędy, które spowodowały, że rozwiązania legislacyjne zawierają wady uniemożliwiające spełnienie celu zakładanego w przepisach unijnych. Zakres ochrony pracowników zaangażowanych w tworzenie i późniejsze funkcjonowanie spółki europejskiej jest $z$ jednej strony zbyt szeroki i niedokładny, a przy tym nie powoduje odpowiedniego zabezpieczenia zgodnego z intencją prawodawcy europejskiego. Dlatego też przepisy Ustawy o spółce wymagają zmian zgodnie z uwagami de lege ferenda wskazanymi w niniejszej publikacji.

\section{Ochrona indywidualnego stosunku pracy oraz uprawnienia osób zaangażowanych $\mathrm{w}$ proces tworzenia spółki europejskiej z siedzibą w Polsce}

Postulat ochrony przewidziany w Dyrektywie 2001/86/WE przejawia się w polskim porządku prawnym poprzez zakaz jednostronnej zmiany na niekorzyść pracownika warunków pracy i płacy, a także wypowiedzenia

\footnotetext{
5 Ustawa z dnia 4 marca 2005 r. o europejskim zgrupowaniu interesów gospodarczych i spółce europejskiej, tekst jednolity: Dz. U. z 2018 r. poz. 551 z późn. zm. (dalej: Ustawa o spółce).
} 
czy rozwiązania stosunku pracy z osobą będącą członkiem specjalnego zespołu negocjacyjnego, organu przedstawicielskiego albo przedstawicielem pracowników w radzie nadzorczej bądź radzie administrującej spółki europejskiej $\mathrm{w}$ czasie trwania mandatu oraz $\mathrm{w}$ okresie roku po jego wygaśnięciu ${ }^{6}$. Wyjątkiem pozwalającym na dokonanie wyżej wymienionych czynności jest zgoda reprezentującej danego pracownika zakładowej organizacji związkowej, a jeżeli pracownik nie jest reprezentowany przez zakładową organizację związkową - zgoda okręgowego inspektora pracy właściwego miejscowo dla siedziby pracodawcy ${ }^{7}$. Ustawa o spółce nie rozstrzyga, jak winien zachować się pracodawca w przypadku milczenia organizacji związkowej, jednak wydaje się zasadne stosowanie odpowiednio przepisów dotyczących chronionych działaczy związku zawodowego ${ }^{8}$ i po bezskutecznym upływie terminu wyznaczonego przez pracodawcę za zajęcie stanowiska przez organizację związkową możliwe powinno być rozwiązanie lub zmiana stosunku pracy z członkiem specjalnego zespołu negocjacyjnego, organu przedstawicielskiego albo przedstawicielem pracowników w radzie nadzorczej bądź radzie administrującej spółki europejskiej. Jest to także uwaga de lege ferenda, ponieważ ustawodawca powinien rozstrzygnąć ten problem jednoznacznie w Ustawie o spółce bez potrzeby sięgania do innych przepisów.

6 Art. 116 Ustawy o spółce: „Pracodawca nie może wypowiedzieć ani rozwiązać stosunku pracy z pracownikiem będącym członkiem specjalnego zespołu negocjacyjnego, organu przedstawicielskiego albo przedstawicielem pracowników w radzie nadzorczej albo radzie administrującej SE w czasie trwania mandatu oraz $\mathrm{w}$ okresie roku po jego wygaśnięciu bez zgody reprezentującej pracownika zakładowej organizacji związkowej, a jeżeli pracownik nie jest reprezentowany przez zakładową organizację związkową - bez zgody okręgowego inspektora pracy właściwego miejscowo dla siedziby pracodawcy." i art. 117 Ustawy o spółce: „Pracodawca nie może zmienić jednostronnie warunków pracy lub płacy na niekorzyść pracownika będącego członkiem specjalnego zespołu negocjacyjnego, organu przedstawicielskiego albo przedstawicielem pracowników w radzie nadzorczej albo radzie administrującej SE w czasie trwania mandatu oraz w okresie roku po jego wygaśnięciu bez zgody reprezentującej pracownika zakładowej organizacji związkowej, a jeżeli pracownik nie jest reprezentowany przez zakładową organizację związkową - bez zgody okręgowego inspektora pracy właściwego miejscowo dla siedziby pracodawcy".

7 R. Markowska-Wolert, Zaangażowanie pracowników w spótce europejskiej, Praca i Zabezpieczenie Społeczne 2005, nr 7, s. 17.

8 Art. 32 ust. 1-12 ustawy z dnia 23 maja 1991 r. o związkach zawodowych, tekst jednolity: Dz. U. z 2019 r. poz. 263 (dalej: Ustawa o związkach zawodowych). 
Analogicznie jak w przypadku działaczy związkowych, również w stosunku do przedstawicieli pracowników w Societas Europea pracodawca ma prawo dokonania wypowiedzenia warunków pracy i płacy bez zgody ustawowo wskazanych organów w ramach zwolnień grupowych ${ }^{9}$, co stanowi wyjątek od tzw. ochrony względnej wymagającej zgody uprawnionych podmiotów ${ }^{10}$.

Analiza ogólnych wytycznych dotyczących ochrony przed rozwiązaniem lub jednostronną i niekorzystną zmianą treści stosunku pracy wskazanych w Dyrektywie 2001/86/WE oraz porównanie przyjętych tam rozwiązań ${ }^{11}$ z Ustawą o spółce prowadzi do wniosku, że w zakresie dotyczącym członków specjalnego zespołu negocjacyjnego wymagania prawa unijnego zostały spełnione ponad miarę, a wręcz - iż nie oddają zamierzonego celu przepisów ochronnych ${ }^{12}$. Polski ustawodawca konstruując regulacje transponujące prawo unijne, wprowadził ochronę przed wypowiedzeniem, wypowiedzeniem zmieniającym na niekorzyść oraz rozwiązaniem umowy o pracę $\mathrm{w}$ czasie trwania mandatu członka specjalnego zespołu negocjacyjnego oraz $\mathrm{w}$ okresie roku od jego wygaśnięcia, mimo że osoba ta pełni swoją funkcję jedynie przez część tego okresu. W przypadku braku wykonywania funkcji $\mathrm{w}$ okresie sprawowania mandatu przez co najmniej rok ochrona mogłaby się kończyćc ${ }^{13}$. Co istotne, działanie polskiego ustawodawcy nie wynikało z obowiązku nałożonego przez

9 Art. 5 ust. 5 ustawy z dnia 13 marca 2003 r. o szczególnych zasadach rozwiązywania z pracownikami stosunków pracy z przyczyn niedotyczących pracowników, tekst jednolity: Dz. U. z 2018 r. poz. 1969 z późn. zm.

10 A. Giedrewicz-Niewińska, Uczestnictwo..., s. 170.

11 Należy zaznaczyć, że konstrukcja przyjęta przez prawodawcę unijnego nie sprzyja prawidłowej realizacji mechanizmów ochronnych, przede wszystkim z uwagi na możliwy różny zakres ochrony w poszczególnych państwach członkowskich. Może to prowadzić do sytuacji, w której przedstawiciele pracowników pochodzący z państwa członkowskiego z większymi uprawnieniami ochronnymi w zakresie stabilności zatrudnienia będą mocniej wpływać na ostateczny kształt zaangażowania pracowników w spółce europejskiej, ponieważ dzięki daleko idącym gwarancjom trwałości stosunku pracy zmniejsza się obawa przedstawicieli strony pracowniczej przed konfliktem z pracodawcą. Zob. tamże, s. 169.

12 A. Miętek, Zaangażowanie pracowników w spółce europejskiej - uwagi "de lege ferenda", Monitor Prawa Pracy 2014, nr 7, s. 352.

13 Analogicznie jak ograniczenie czasowe wprowadzone w art. 32 ust. 2 Ustawy o związkach: „Ochrona, o której mowa w ust. 1, przysługuje przez okres określony uchwałą zarządu, a po jego upływie - dodatkowo przez czas odpowiadający połowie okresu określonego uchwałą, nie dłużej jednak niż rok po jego upływie". 
Dyrektywę 2001/86/WE. Zgodnie bowiem z jej przepisami oraz rozwiązaniami powielonymi w Ustawie o spółce członkowie specjalnego zespołu negocjacyjnego wykonują swoje funkcje do momentu zawarcia porozumienia w sprawie zaangażowania pracowników w spółce europejskiej lub ewentualnie do czasu podjęcia uchwały o nierozpoczynaniu negocjacji lub zakończeniu już rozpoczętych negocjacji. Dodatkowo specjalny zespół negocjacyjny może działać w przypadku, gdy po 2 latach od podjęcia uchwały o nierozpoczynaniu negocjacji lub zakończeniu już rozpoczętych negocjacji pisemny wniosek zostanie sformułowany przez co najmniej $10 \%$ pracowników zatrudnionych w spółce europejskiej, jej spółkach zależnych i zakładach lub ich przedstawicieli. Okres 2 lat może być skrócony przez strony, co nie zmienia faktu, że pomiędzy momentem podjęcia uchwały a ponownym działaniem zespołu jego członkowie nie wykonują żadnych czynności związanych z dialogiem społecznym. Zgodnie zaś z art. 69 Ustawy o spółce mandat członków specjalnego zespołu negocjacyjnego trwa do momentu ustania stosunku pracy lub zrzeczenia się funkcji, ewentualnie do momentu cofnięcia rekomendacji przez daną organizację związkową w przypadku przedstawicieli reprezentatywnych związków zawodowych.

Omawiana konstrukcja prawna nie jest do końca spójna z pkt 5 preambuły Rozporządzenia Nr 2157/2001, zgodnie z którym państwa członkowskie zobowiązane są zapewnić, aby przepisy, które stosuje się do spółek, nie powodowały dyskryminacji wynikającej z nieuzasadnionego traktowania spółek europejskich. W doktrynie pojawił się postulat, by ustawodawca zastąpił obecną regulację rozwiązaniem zbliżonym do przyjętego w Ustawie o związkach zawodowych dotyczących komitetu założycielskiego. Osobom działającym w ramach tego ciała przysługuje ochrona przed rozwiązaniem, wypowiedzeniem stosunku pracy i jednostronną zmianą warunków pracy i płacy przez okres 6 miesięcy od dnia utworzenia komitetu założycielskiego zakładowej organizacji związkowej, jednakże nie więcej niż 3 pracownikom imiennie wskazanym uchwałą komitetu założycielskiego. Zatem w odniesieniu do członków specjalnego zespołu negocjacyjnego ustawa miałaby przewidywać, że ich mandat trwa do momentu zawarcia porozumienia o zaangażowaniu w spółce europejskiej bądź podjęcia uchwały o nierozpoczynaniu negocjacji lub przerwaniu rozpoczętych negocjacji, a ochrona przysługuje podczas trwania mandatu i przez rok po jej zakończeniu ${ }^{14}$. Jeżeli nato-

14 A. Miętek, Zaangażowanie..., s. 352. 
miast nie ostanie osiągnięte porozumienie o zaangażowaniu, a po 2 latach doszłoby do ponownego zebrania się zespołu negocjacyjnego, wówczas analogicznie ochrona mogłaby przysługiwać do czasu zawarcia porozumienia lub ewentualnej decyzji o jego braku i w okresie roku od zawarcia. W przypadku stosowania zasad standardowych, ewentualne negocjacje co do późniejszego zawarcia porozumienia w imieniu pracowników prowadzi nie specjalny zespół negocjacyjny, lecz organ przedstawicielski, którego członkom także przysługiwałaby analogiczna ochrona stosunku pracy $^{15}$. Wydaje się jednak, że takie ograniczenie ochrony mogłoby powodować obawy przedstawicieli pracowników do podejmowania decyzji o zakończeniu negocjacji lub ich nierozpoczynaniu, ponieważ $w$ takim wypadku szybciej traciliby przyznane im uprawnienia, a tym samym pracodawca miałby możliwość rozwiązania stosunku pracy z osobami, które starają się uzyskać jak najdalej idące mechanizmy zaangażowania, czyli np. partycypację w organach zarządzających Societas Europea. Celem osób reprezentujących pracodawcę mogłaby być chęć uzyskania łatwiejszych do spełnienia wymogów dialogu, czyli np. wyłącznie informowania pracowników, dzięki wyłączeniu aktywnych reprezentantów pracowników, w sytuacji reaktywacji działań specjalnego zespołu negocjacyjnego.

Należy jednak zgodzić się z możliwością ograniczenia uprawnień ochronnych w takim samym zakresie, w jakim postulowane są zmiany co do działaczy związkowych. W doktrynie trafnie krytykuje się szeroki zakres ochrony przedstawicieli strony pracowniczej działających w ramach związku zawodowego. Najwięcej kontrowersji budzi ochrona przed rozwiązaniem stosunku pracy bez wypowiedzenia z winy pracownika, czyli przypadku, gdy uprawnienia ochronne wykorzystywane są do zapobieżenia skutkom działań lub zachowań niezwiązanych z pełnioną funkcją, a godzącym w podstawowe obowiązki pracownicze. Zagadnienie to było przedmiotem rozważań na gruncie Ustawy o związkach zawodowych $^{16}$, natomiast ze względu na synonimiczność rozwiązań przyjętych

15 Tamże, s. 352.

16 Zarówno doktryna, jak i orzecznictwo pozostają zgodnie, że ze względu na treść art. 8 ustawy z dnia 26 czerwca 1974 r. - Kodeks pracy, tekst jednolity: Dz. U. z 2019 r. poz. 1040 (dalej: K.p.) należy odmówić ochrony i przywrócenia do pracy działaczowi związkowemu, z którym pracodawca rozwiązał stosunek pracy bez zgody odpowiedniego organu zakładowej organizacji związkowej, wskazując konkretną winę pracownika. Zob. wyrok SN z dnia 12 września 2000 r., I PKN 27/00, OSN 2002, nr 7, poz. 106; wyrok SN z dnia 27 lutego 1997 r., I PKN 23/97, OSN 1997, nr 21, poz. 419; A. Dral, Problem liberalizacji, deregulacji 
do przedstawicieli pracowników w spółce europejskiej również będzie miało zastosowanie.

Poza przepisami dotyczącymi ochrony indywidualnego stosunku pracy polski ustawodawca przyznał także szczególne uprawnienia członkom specjalnego zespołu negocjacyjnego, członkom organu przedstawicielskiego, przedstawicielom pracowników wykonujących funkcje w ramach procedury informowania pracowników i konsultowania oraz przedstawicielom pracowników w organie nadzorczym lub zarządzającym spółki europejskiej, którzy są pracownikami spółki europejskiej, jej spółek zależnych lub zakładów czy też spółki uczestniczącej. Pracownik, który wykonuje czynności w ramach wspomnianych wyżej funkcji, ma prawo do zwolnienia od pracy zawodowej z zachowaniem prawa do wynagrodzenia na zasadach dotyczących członka zarządu zakładowej organizacji związkowej określonych w art. 31 ust. 3 Ustawy o związkach zawodowych, jednak wyłącznie w związku z udziałem w pracach przedmiotowych organów. Przedmiotowe uprawnienie wydaje się korzystne dla osiągnięcia założeń dialogu społecznego i istoty zaangażowania pracowników w spółce europejskiej, choć należy podkreślić, że także w tym zakresie polski ustawodawca nie był zmuszony do wprowadzania tego rodzaju konstrukcji legislacyjnej. Gdyby jednak takie rozwiązanie nie zostało wprowadzone, powodowałoby to trudności $\mathrm{w}$ prawidłowym i aktywnym reprezentowaniu strony pracowniczej przez wybranych przedstawicieli, ponieważ musieliby oni korzystać np. $z$ urlopu wypoczynkowego niezgodnie z jego przeznaczeniem lub też z urlopu bezpłatnego, pozbawiając się dochodu i licząc na dobrą wolę ze strony pracodawcy.

Krytyce poddać należy jednak odesłanie przez ustawodawcę do art. 31 ust. 3 Ustawy o związkach, analizując ten przepis z punktu widzenia prawidłowości legislacji. Zgodnie ze wspomnianym aktem prawnym pracownik ma prawo do zwolnienia od pracy zawodowej z zachowaniem prawa do wynagrodzenia na czas niezbędny do wykonania doraźnej czynności wynikającej z jego funkcji związkowej, jeżeli czynność ta nie może być wykonana w czasie wolnym od pracy. Przepis ten odnosi

i uelastycznienia ochrony trwałości stosunku pracy w polskim prawie pracy, Praca i Zabezpieczenie Społeczne 2009, nr 5, s. 16; M. Latos-Miłkowska, Szczególna ochrona trwałości stosunku pracy a ochrona interesu pracodawcy, w: Ochrona trwałości stosunku pracy w społecznej gospodarce rynkowej, red. G. Goździewicz, Warszawa 2010, s. 249; B. Rutkowska, Szczególna ochrona trwałości stosunku pracy przedstawicieli pracowników - uwagi de lege ferenda, w: Ochrona trwatości..., s. 268. 
się zatem do sytuacji poniekąd nadzwyczajnej, a za taką trudno uznać chociażby obrady specjalnego zespołu negocjacyjnego, które mogą być z góry zaplanowane ${ }^{17}$. Co więcej, rozwiązanie przyjęte przez polskiego ustawodawcę w Ustawie o związkach zawodowych obejmuje swoim zakresem nie tylko członków zarządu zakładowej organizacji związkowej, lecz także innych pracowników, którzy pełnią określone funkcje związkowe rozumiane szeroko ${ }^{18}$. Tymczasem konstrukcja art. 118 Ustawy o spółce wprost odnosi się do z góry określonego kręgu podmiotowego, tj. pracowników będących członkami specjalnego zespołu negocjacyjnego, organu przedstawicielskiego lub przedstawicielem pracowników w radzie nadzorczej albo radzie administrującej Societas Europea. Dlatego też odwołanie użyte przez polskiego ustawodawcę może powodować niepotrzebne wątpliwości.

Reasumując, co do zasady polska regulacja dotycząca ochrony indywidualnego stosunku pracy oraz uprawnień osób zaangażowanych w proces tworzenia spółki europejskiej z siedzibą w Polsce mimo pewnych niedoskonałości legislacyjnych oraz wykraczania poza ramy nałożone Dyrektywą 2001/86/WE może być oceniona pozytywnie. W przypadku braku wprowadzenia określonych mechanizmów można byłoby postawić tezę, że wspomniany akt prawny nie został transponowany w sposób prawidłowy, a dodatkowo z pewnością komplikowałoby to i tak niełatwy dialog społeczny w formowaniu Societas Europea.

17 Przedstawiciele doktryny w sposób wyczerpujący analizowali możliwość uznania danej czynności za doraźną i trudno uznać, że np. udział w z góry zaplanowanych posiedzeniach może uzyskać przymiot takiego działania. Zob. K.W. Baran, w: Komentarz do ustawy o zwiazkach zawodowych, red. K.W. Baran, 2019 [baza danych LEX], uwagi do art. 31 ust. 3; J. Żołyński, Doraźne zwolnienie działacza zwiazkowego - od pracy z zachowaniem prawa do wynagrodzenia - glosa - II PK 322/16, Monitor Prawa Pracy 2019, nr 3, s. 48-52; tenże, Zwolnienie działacza związowego z obowiazku świadczenia pracy w celu dokonywania czynności doraźnych, Monitor Prawa Pracy 2013, nr 10, s. 516-519; K. Kulig, Doraźne czynności związkowe. Prawo podmiotowe pracownika czy prawo organizacji zwiazkowej?, Praca i Zabezpieczenie Społeczne 2015, nr 8, s. 9-15; K. Rączka, Urlopy bezptatne i zwolnienia od pracy działaczy zwiazkowych, Praca i Zabezpieczenie Społeczne 2013, nr 11, s. 19-24.

18 J. Żołyński, Zwolnienie..., s. 516-519. 


\section{Zabezpieczenie zbiorowych interesów pracowniczych przy procedurach dialogowych w spółce europejskiej z siedzibą w Polsce}

Przepisy prawa unijnego, czyli Dyrektywa 2001/86/WE oraz Rozporządzenie Nr 2157/2001, regulują przede wszystkim proces zaangażowania pracowników na etapie tworzenia spółki europejskiej, a tym samym mechanizmy ochronne dla przedstawicieli strony pracowniczej koncentrują się na zapobieżeniu rozwiązania stosunku pracy lub jego jednostronnej zmiany niekorzystnej dla pracownika na etapie negocjacyjnym kształtującym dialog społeczny w Societas Europea. Analizy wymagają jednak również rozwiązania, które pozwalają zabezpieczyć interes pracowników europejskiej spółki akcyjnej we współzarządzaniu zakładem pracy już po zawarciu porozumienia lub przyjęciu stosowania zasad standardowych.

Dyrektywa 2001/86/WE w pkt 18 preambuły przewiduje prymat zasady ochrony nabytych praw pracowników. Oznacza to, że prawa pracowników w zakresie zaangażowania, istniejące przed zmianami strukturalnymi w Societas Europea, powinny być podstawą praw pracowników także po przeprowadzeniu tych zmian. Jednocześnie nie wyjaśniono rozumienia sformułowania „zmiany strukturalne w spółce europejskiej” ani nie rozstrzygnięto, czy w przypadku „zmian strukturalnych" strony zobowiązane są podjąć nowe negocjacje w sprawie mechanizmów uczestnictwa pracowników, co mogłoby być rozumiane jako mechanizm ochronny dla praw strony pracowniczej zabezpieczonej $\mathrm{w}$ trakcie procesu negocjacyjnego mającego miejsce przy tworzeniu europejskiej spółki akcyjnej. Projekt Parlamentu Europejskiego dotyczący wprowadzenia pkt 7a w preambule Dyrektywy 2001/86/WE nie zyskał aprobaty. Przewidywał on zobowiązanie państw członkowskich do przeprowadzenia negocjacji $\mathrm{w}$ sprawie przyszłych praw pracowników w zakresie zaangażowania, także w przypadku zmian strukturalnych w spółce europejskiej ${ }^{19}$. Podobnie jak w przypadku ochrony indywidualnego stosunku pracy prawodawca unijny uznał, że najwłaściwszym rozwiązaniem będzie powierzenie decyzji w tym zakresie poszczególnym państwom członkowskim, które najlepiej będą w stanie uwzględnić

19 G. Kleinsorge, Europäische Gesellschaft und Beteiligungsrechte der Arbeitnehmer, Recht der Arbeit 2002, t. 55, nr 6, s. 351. 
specyfikę krajowych porządków prawnych i skorzystają z już istniejących analogicznych rozwiązańn ${ }^{20}$.

Realizując założenia prawa unijnego, polski ustawodawca uwzględnił nie tylko obowiązek wynikający z pkt 18 preambuły Dyrektywy 2001/86/ WE, lecz także z jej art. 11, zgodnie z którym każde państwo członkowskie powinno przyjąć odpowiednie środki w celu zapobiegania nadużyciom dotyczącym pozbawienia pracowników prawa do uczestnictwa lub zawieszenia takich praw. Kwestie te reguluje treść art. 120 Ustawy o spółce. Przepis ten stanowi, że jeżeli w już zarejestrowanej spółce europejskiej, w jej spółkach zależnych lub zakładach wystąpią istotne zmiany dotyczące ich struktury, liczby pracowników, jak również miejsca jej rejestracji, wskazujące na zamiar pozbawienia lub ograniczenia pod jakimkolwiek względem praw pracowników w zakresie ich zaangażowania we współzarządzanie zakładem pracy, konieczne jest przeprowadzenie negocjacji $\mathrm{w}$ celu zawarcia porozumienia w zmienionych warunkach ${ }^{21}$.

"Istotne zmiany" dotyczą nie tylko samej Societas Europea, ale jej spółek zależnych i zakładów oraz zmianę miejsca rejestracji. Przedmiotem zmian może być struktura lub liczba pracowników, jednak polski ustawodawca nie zdecydował się na dalsze szczegółowe wskazanie, jak należy rozumieć te pojęcia, co z kolei nakłada obowiązek rozpatrywania

20 A. Giedrewicz-Niewińska przywołuje w tym kontekście rozwiązania austriackie i niemieckie, gdzie zagadnienie zmian strukturalnych w spółce europejskiej zostało uregulowane w sposób szczegółowy. W ramach tego porządku prawnego zdecydowano się wymienić przykłady zmian strukturalnych, wśród których znajdują się także znaczące zmiany liczby zatrudnionych osób w Societas Europea i w jej spółkach córkach (§ 228 ust. 2 Arbeitverfassungsgesetz vom 14.12.1973, BGBI. 1974, s. 22). Z kolei niemiecki ustawodawca nie zdefiniował pojęcia zmian strukturalnych, jak również nie dokonał ich przykładowego wyliczenia jak w modelu austriackim, jednak przewidziano, w przypadku ich wystąpienia w europejskiej spółce akcyjnej, konieczność ponownego przeprowadzenia negocjacji w kwestii zaangażowania pracowników, który to proces podlega kontroli sądu rejestrowego (§18 Gesetz vom 22.12.2014 über die Beteiligung der Arbeitnehmer in der Europäischen Gesellschaft [SE-Beteiligungsgesetz; SEBG], BGBI. I, s. 3675, 3686). Zob. A. Giedrewicz-Niewińska, Uczestnictwo..., s. 134.

${ }^{21}$ Ponowny proces negocjacyjny odbywa się w niemalże identycznym zakresie, jak w przypadku formowania spółki europejskiej. Właściwie jedyną różnicą pozostaje podmiot występujący z żądaniem ich podjęcia, czyli organ przedstawicielski. Negocjacje odbywają się pomiędzy tym ostatnim podmiotem a spółką europejską. Organowi przedstawicielskiemu przysługują prawa i obowiązki specjalnego zespołu negocjacyjnego. Nie ma również różnic w przypadku nieosiągnięcia porozumienia, ponieważ zastosowanie znajdą wtedy zasady standardowe - art. 84-86 Ustawy o spółce. 
każdej sytuacji indywidualnie i dokonywanie każdorazowo oceny, czy konieczne jest rozpoczęcie procesu negocjacyjnego. Doktryna zalicza do „zmian dotyczących struktury" połączenie, podział spółki europejskiej, zakładów i spółek zależnych ${ }^{22}$. Kontrowersje budzi zakwalifikowanie do tej grupy zmiany systemu monistycznego administrowania spółką na system dualistyczny ${ }^{23}$. Nie ma natomiast wątpliwości, że zmianą w zakresie „liczby pracowników” będzie zatrudnienie pracowników, w sytuacji jeśli wcześniej spółka europejska, która nie była związana żadnym stosunkiem pracy, zaczęła zatrudniać. Co więcej, zwiększenie zatrudnienia może spowodować przekroczenie progów procentowych, od których zależy obecność zasad standardowych odnoszących się do partycypacji ${ }^{24}$.

Zmiany w strukturze Societas Europea bez wątpliwości powoduje także dokonanie przeniesienia miejsca rejestracji spółki europejskiej ${ }^{25}$. Modyfikacja w tym zakresie zasadniczo wpływa na sposób zaangażowania pracowników, jeśli skorzystano z zasad standardowych, ponieważ zmiana miejsca siedziby europejskiej spółki akcyjnej może skutkować także

22 G. Kleinsorge, Europäische..., s. 351.

23 Za zakwalifikowaniem tej zmiany jako istotnej w rozumieniu art. 120 Ustawy o spółce opowiada się A. Giedrewicz-Niewińska, Uczestnictwo..., s. 135. W doktrynie niemieckiej zaś zmiana tego rodzaju nie uzyskuje tego przymiotu, por. F. Linden, Die Mitbestimmungsvereinbarung der dualistisch verfassten Societas Europaea, Waabs 2012, s. 205-206. Autor niniejszego opracowania nie może zgodzić się z poglądem prezentowanym $\mathrm{w}$ niemieckiej doktrynie, ponieważ trudno uznać, że zmiana tego rodzaju pozostanie bez wpływu na dialog społeczny w spółce, nawet w sytuacji jego najmniej aktywnej formy, jaką jest informowanie, ponieważ może się okazać, iż po dokonaniu zmiany w zakresie administrowania zobowiązany do przekazywania informacji będzie inny organ europejskiej spółki akcyjnej. W przypadku najdalej idącej formy zaangażowania, czyli partycypacji w organach Societas Europea, pogląd doktryny niemieckiej nie znajduje żadnego uzasadnienia.

24 Art. 7 ust. 2 Dyrektywy 2001/86/WE

${ }_{25}$ Zmianę miejsca rejestracji spółki europejskiej w zakresie prawa unijnego reguluje art. 8 Rozporządzenia Nr 2157/2001. Polski ustawodawca również w Ustawie o spółce (art. 48-57) powielił w znacznej części rozwiązania prawodawcy unijnego. Statutowa siedziba Societas Europea może zostać przeniesiona do innego państwa członkowskiego bez likwidacji spółki europejskiej w państwie pierwotnym, jak również bez procesu rejestracji nowej osoby prawnej w państwie docelowym. Uregulowanie to ma na celu odróżnienie europejskiej spółki akcyjnej od podmiotów opartych o krajowe porządki prawne, które niejednokrotnie przewidują, że podjęcie uchwały o przeniesieniu siedziby statutowej za granicę jest równoznaczne z rozwiązaniem danej spółki. Zob. A. Rachwał, w: Kodeks spółek handlowych. Komentarz, t. 5: Pozakodeksowe prawo handlowe, red. S. Sołtysiński, A. Szajkowski, A. Szumański, J. Szwaja, Warszawa 2008, s. 1346. 
zmianą w zakresie zasad standardowych. Wynika to przede wszystkim $\mathrm{z}$ różnic pomiędzy sposobem wdrożenia zasad standardowych $\mathrm{w}$ poszczególnych krajowych porządkach prawnych.

Rozporządzenie Nr 2157/2001 w nieznacznym stopniu reguluje zapewnienie praw pracowników do zaangażowania w przypadku zmiany miejsca rejestracji spółki europejskiej. Jedyny dodatkowy obowiązek związany z przeprowadzeniem tej procedury polega na wskazaniu $\mathrm{w}$ planie przeniesienia, publikowanym przez organ zarządzający lub administrujący, wszelkich konsekwencji tego przeniesienia dla zaangażowania pracowników spółki, a informacje w tym zakresie muszą się znaleźć w sprawozdaniu wyjaśniającym, które uzasadnia aspekty prawne i ekonomiczne przeniesienia. Uregulowanie to ma na celu właśnie ochronę nabytych praw pracowników do informacji i przeprowadzenia konsultacji z pracownikami w przypadku przewidywanych zmian w spółce europejskiej.

Aspektem ochrony jest także konieczność wydania przez właściwy organ zaświadczenia potwierdzającego dopełnienie aktów i czynności prawnych niezbędnych do przeniesienia. Właściwość organu jest określana przez państwo członkowskie, w którym przenoszona Societas Europea posiada swoją statutową siedzibę. Zgodnie z polskim porządkiem prawnym w przypadku podmiotu przenoszącego siedzibę na teren Rzeczypospolitej Polskiej organem uprawnionym w powyższym kontekście jest sąd rejestrowy właściwy według siedziby statutowej spółki europejskiej ${ }^{26}$. Spółka może zostać zarejestrowana i zakończyć procedurę przenoszenia dopiero po wydaniu odpowiedniego zaświadczenia i wykazaniu, że dokonano wszystkich czynności wymaganych do rejestracji spółki w państwie, w którym mieści się jej nowa statutowa siedziba. Pewnego rodzaju instytucją ochronną jest zatem badanie przez sąd rejestrowy prawidłowości w zakresie zaangażowania pracowników, choć należy podkreślić, że ogranicza się to jedynie do kontroli o charakterze formalnym. To postępowanie kontrolne jest także ograniczone ze względu na trudności występujące przy badaniu zakresu podmiotów zainteresowanych postępowaniem rejestrowym i możliwości przyznania im statusu wnioskodawcy lub uczestnika ${ }^{27}$.

26 Art. 4 ust. 1 Ustawy o spółce.

27 Zob. N. Banaś, Europejska spótka akcyjna w postepowaniu rejestrowym, Warszawa 2012, s. 79 i nast. 
Konstrukcja art. 120 Ustawy o spółce może budzić kontrowersje, ponieważ uzależnia przeprowadzenie ponownych negocjacji od zmian wskazujących na zamiar pozbawienia lub ograniczenia pod jakimkolwiek względem praw pracowników w zakresie ich zaangażowania we współzarządzaniu zakładem pracy. Polski prawodawca nawiązał we wspomnianym przepisie do treści pkt 3 preambuły Dyrektywy 2001/86/WE, zgodnie z którym ustanowienie spółki europejskiej nie może pociągnąć za sobą zniknięcia lub ograniczenia uczestnictwa pracowników istniejącego w spółkach uczestniczących w powstaniu spółki europejskiej. Zabrakło jednak $\mathrm{w}$ polskich przepisach wyjaśnienia, co należy rozumieć przez zamiar pozbawienia lub ograniczenia zaangażowania pracowników, a to z kolei powoduje osłabienie mechanizmu ochronnego, ponieważ konieczne jest każdorazowe porównywanie zakresu formy dialogu przed wystąpieniem istotnych zmian z okresem, jaki zaistniał po ich wejściu w życie.

Polski porządek prawny nie rozstrzygnął kwestii uchylania się od przeprowadzenia ponownych negocjacji w przypadku stwierdzenia wystąpienia istotnych zmian $\mathrm{w}$ już funkcjonującej spółce europejskiej, w jej spółkach zależnych lub zakładach. Wydaje się zasadne stwierdzenie, że podobnie jak $\mathrm{w}$ przypadku systemu niemieckiego ${ }^{28}$ zastosowanie znajdą tutaj przepisy o charakterze prawnokarnym, choć penalizacja tego czynu nie została uchwalona wprost. Jednakże stosując wykładnię systemową, można dojść do wniosku, że nieprzeprowadzenie ponownych negocjacji w stanie faktycznym, wynikającym z art. 120 Ustawy o spółce, będzie uniemożliwiało lub utrudniało działanie organu przedstawicielskiego i podlegało karze ograniczenia wolności albo grzywny.

\section{Prawnokarna ochrona pracowników $\mathrm{w}$ procesie zaangażowania w spółce europejskiej z siedzibą w Polsce}

Polski ustawodawca zdecydował się wprowadzić sankcje karne, które mają na celu wzmocnić ochronę procesu zaangażowania pracowników w spółce europejskiej ${ }^{29}$. Przyjęta konstrukcja legislacyjna jest skromna

28 Gesetz vom 22.12.2014 r. über die Beteiligung der Arbeitnehmer in der Europäischen Gesellschaft (SE-Beteiligungsgesetz; SEBG), BGBI. I, s. 3675, 3686.

29 Art. 133 Ustawy o spółce. 
objętościowo, ponieważ mieści się w jednym artykule Ustawy o spółce, jednak treściowo obejmuje dużą liczbę potencjalnych zdarzeń, które mogą spowodować zastosowanie przedmiotowych przepisów. Kara ograniczenia wolności albo grzywny może zostać w pierwszej kolejności orzeczona wobec osoby, która będąc członkiem właściwego organu Societas Europea, spółki uczestniczącej, spółki zależnej albo kierownictwa zakładu, znajdujących się na terytorium Rzeczypospolitej Polskiej, niezależnie od miejsca statutowej siedziby spółki europejskiej, uniemożliwia lub utrudnia utworzenie specjalnego zespołu negocjacyjnego lub organu przedstawicielskiego, a w szczególności nie powiadamia uprawnionych organizacji związkowych o terminie i sposobie przeprowadzenia wyborów członków specjalnego zespołu negocjacyjnego. Również uniemożliwianie lub utrudnianie działania tego zespołu lub organu przedstawicielskiego będzie nakładało wymienioną wyżej sankcję. Ostatnia sytuacja, która może powodować realizację dyspozycji art. 133 Ustawy o spółce, to postępowanie mające znamiona dyskryminacji członka specjalnego zespołu negocjacyjnego, członka organu przedstawicielskiego lub przedstawiciela pracowników w związku z pełnioną przez niego funkcją. Należy podkreślić, że zakres adresatów tej normy jest mocno ograniczony, wobec czego dopuszczalne jest działanie, które realizując ten sam cel, czyli utrudnianie dialogu społecznego w spółce europejskiej, nie spotka się z żadnymi konsekwencjami natury prawnokarnej ze względu jedynie na fakt, iż osoba popełniająca dany czyn nie będzie członkiem właściwego organu europejskiej spółki akcyjnej, spółki uczestniczącej, spółki zależnej albo kierownictwa zakładu, znajdujących się na terytorium Rzeczypospolitej Polskiej.

Jak już zostało wspomniane, pojęcie uniemożliwiania lub utrudniania, którymi posługuje się polski ustawodawca, charakteryzując działania sprawcy czynu zabronionego, mogą przybrać wiele postaci i form, wobec czego nie jest możliwe ich jednoznaczne oraz całościowe wyliczenie. Karze podlegają jedynie te działania, których skutkiem jest faktyczne utrudnianie lub uniemożliwianie realizacji dialogu społecznego w spółce europejskiej ${ }^{30}$, wobec czego nie ma wątpliwości, że mowa tutaj o wykroczeniu skutkowym. Zatem postępowanie, które jedynie ma na celu uniemożliwianie lub utrudnianie, ale faktycznie nie oddziałuje na sam proces negocjacji pomiędzy stroną pracowniczą a pracodawcą, nie będzie poddane sankcji z omawianego przepisu.

30 Z. Kukuła, Odpowiedzialność karna w spółce europejskiej, Prawo Spółek 2009, nr 3, s. 30. 
Jeżeli chodzi o dyskryminację, to można odnieść się nie tylko do potocznego rozumienia tego pojęcia, ale należy odczytywać treść art. 133 Ustawy o spółce w kontekście wykładni systemowej i art. $11^{3}$ K.p., regulującego jedną z podstawowych zasad prawa pracy. Przywołany przepis postuluje generalny zakaz jakiejkolwiek dyskryminacji (bezpośredniej lub pośredniej) w zatrudnieniu, w szczególności ze względu na przynależność związkową. W omawianej regulacji dyskryminacja musi być ściśle powiązana $\mathrm{z}$ wykonywaniem funkcji w trakcie realizacji dialogu społecznego.

Procedura regulująca odpowiedzialność za uniemożliwianie lub utrudnianie dialogu społecznego w spółce europejskiej czy też dyskryminację osoby zatrudnionej ze względu na wykonywaną przez nią funkcję w toku uzgadniania sposobu zaangażowania pracowników jest regulowana przez Kodeks postępowania w sprawach o wykroczenia ${ }^{31}$, co obniża rangę czynu zabronionego. Jednak należy zaznaczyć, że nie konkretna procedura, a faktyczna możliwość egzekwowania przepisów i nakładania sankcji ma tutaj funkcje ochronne, a samo wprowadzenie przedmiotowej regulacji można oceniać pozytywnie. Rolę oskarżyciela publicznego pełni w tych sprawach inspektor pracy, co także zasługuje na aprobatę, ponieważ nie powoduje konieczności angażowania organów obarczonych koniecznością prowadzenia postępowań w bardziej ważkich czynach zabronionych, a jednocześnie pozwala na uwzględnienie specyfiki prawa pracy, którą bezsprzecznie inspektorzy pracy rozumieją.

\section{Zakończenie}

Ochrona praw pracowników w spółce europejskiej z siedzibą w Polsce ma kilka aspektów. Można mówić o mechanizmach ochronnych w zakresie indywidualnego stosunku pracy osób pełniących funkcje $\mathrm{w}$ toku formowania Societas Europea i uzgadniania przez przedstawicieli pracowników z pracodawcą mechanizmów zaangażowania. Nie są dopuszczalne jednostronna zmiana treści stosunku pracy lub rozwiązanie umowy o pracę z takimi osobami, jak również ich dyskryminowanie ze względu

31 Ustawa z dnia 24 sierpnia 2001 r. - Kodeks postępowania w sprawach o wykroczenia, tekst jednolity: Dz. U. z 2019 r. poz. 1120 z późn. zm. 
na wykonywane czynności. Polska regulacja daje również podstawy do stwierdzenia, że zbiorowe interesy pracowników są w pewien sposób chronione poprzez obowiązek ponowienia dialogu społecznego i procedur negocjacyjnych $\mathrm{w}$ przypadku istotnych zmian $\mathrm{w}$ funkcjonowaniu spółki europejskiej. Niejako dodatkowym zabezpieczeniem są wprowadzone przez polskiego ustawodawcę sankcje karne, które penalizują utrudnianie lub uniemożliwianie uzgadniania oraz realizacji sposobów zaangażowania pracowników.

Wszystkie te regulacje nie są jednak pozbawione wad natury legislacyjnej, co pokazały powyższe rozważania. W kontekście indywidualnego stosunku pracy problematyczna jest długość ochrony oraz jej zakres przedmiotowy, który wydaje się zbyt szeroki. Podobnie niedoskonałe są przepisy dające uprawnienia do prawidłowego uczestnictwa w sposobach dialogu, które korzystają z wzorów z Ustawy o związkach zawodowych, jednak z przepisów dotyczących czynności wcześniej niezaplanowanych. W przypadku norm mających na celu dbanie o interesy zbiorowe największy problem rodzi zdefiniowanie istotności oraz zakresu zmian, które powodują konieczność wznowienia negocjacji ze stroną pracowniczą. Podobnie w przypadku przepisów o charakterze prawnokarnym element kontrowersyjny stanowi dokładne określenie przedmiotu ochrony przy jednoczesnym nietrafnym ujęciu podmiotowym omawianego wykroczenia. Wydaje się zatem konieczne dokonanie korekt natury legislacyjnej, by wspomniane wątpliwości nie występowały.

\section{Bibliografia}

Banaś N., Europejska spótka akcyjna w postepowaniu rejestrowym, Warszawa 2012.

Baran K.W., w: Komentarz do ustawy o zwiazkach zawodowych, red. K.W. Baran, 2019 [baza danych LEX], uwagi do art. 31 ust. 3.

Dral A., Problem liberalizacji, deregulacji i uelastycznienia ochrony trwałości stosunku pracy w polskim prawie pracy, Praca i Zabezpieczenie Społeczne 2009, nr 5.

Felten E., Directive 2001/86/EC supplementing the Statute for a European company with regard to the involvement of employees, w: International and European Labour Law, red. E. Ales, M. Bell, O. Deinert, S. Robin-Olivier, Baden Baden 2018.

Giedrewicz-Niewińska A., Uczestnictwo pracowników w spółce europejskiej, Warszawa 2015. 
Kleinsorge G., Europäische Gesellschaft und Beteiligungsrechte der Arbeitnehmer, Recht der Arbeit 2002, t. 55, nr 6.

Kukuła Z., Odpowiedzialność karna w spótce europejskiej, Prawo Spółek 2009, nr 3.

Kulig K., Doraźne czynności związowe. Prawo podmiotowe pracownika czy prawo organizacji zwiazkowej?, Praca i Zabezpieczenie Społeczne 2015, nr 8.

Kurcz B., Kurcz M., Spótka Europejska - Societas Europea, Prawo Unii Europejskiej 2002, nr 1.

Latos-Miłkowska M., Szczególna ochrona trwałości stosunku pracy a ochrona interesu pracodawcy, w: Ochrona trwałości stosunku pracy w społecznej gospodarce rynkowej, red. G. Goździewicz, Warszawa 2010.

Loranc J., Spótka europejska a przepisy polskie, Rejent 2001, nr 6.

Linden F., Die Mitbestimmungsvereinbarung der dualistisch verfassten Societas Europea, Waabs 2012.

Markowska-Wolert R., Zaangażowanie pracowników w spółce europejskiej, Praca i Zabezpieczenie Społeczne 2005, nr 7.

Miętek A., Zaangażowanie pracowników w spółce europejskiej - uwagi „de lege feren$d a^{\prime \prime}$, Monitor Prawa Pracy 2014, nr 7.

Minas M., Spótka europejska w pracach Komisji Wspólnot Europejskich, Kwartalnik Prawa Prywatnego 1996, z. 1.

Opalski A., Europejskie prawo spółek - zasady prawa europejskiego i ich wpływ na polskie prawo spółek, Warszawa 2010.

Rachwał A., w: Kodeks spółek handlowych. Komentarz, t. 5: Pozakodeksowe prawo handlowe, red. S. Sołtysiński, A. Szajkowski, A. Szumański, J. Szwaja, Warszawa 2008.

Rączka K., Urlopy bezpłatne i zwolnienia od pracy działaczy zwiąkowych, Praca i Zabezpieczenie Społeczne 2013, nr 11.

Rutkowska B., Szczególna ochrona trwałości stosunku pracy przedstawicieli pracowników - uwagi de lege ferenda, w: Ochrona trwałości stosunku pracy w społecznej gospodarce rynkowej, red. G. Goździewicz, Warszawa 2010.

Siemiątkowski T., Potrzeszcz R., Spótka europejska w polskiej typologii spótek handlowych, cz. 1, Przegląd Prawa Handlowego 2005, nr 11.

Szumański A., Europejskie prawo spółek, w: Prawo spółek, red. W. Włodyka, Kraków 1996.

Szumański A., Spótka europejska, Kwartalnik Prawa Prywatnego 1997, z. 2.

Wratny J., Fenomen partycypacji pracowniczej w nurcie przemian stosunków pracy, Warszawa 2019.

Żołyński J., Zwolnienie działacza związowego z obowiązku świadczenia pracy w celu dokonywania czynności doraźnych, Monitor Prawa Pracy 2013, nr 10.

Żołyński J., Doraźne zwolnienie działacza związkowego - od pracy z zachowaniem prawa do wynagrodzenia - glosa - II PK 322/16, Monitor Prawa Pracy 2019, nr 3. 


\section{Streszczenie}

Zaangażowanie pracowników jest jedną z form realizacji szerszej koncepcji, jaką jest dialog społeczny. Spółka europejska jest to podmiot ponadnarodowy, który prowadzi działalność na terenie wielu państw Unii Europejskiej. Opracowanie poddaje analizie mechanizmy ochronne $\mathrm{w}$ zakresie zaangażowania pracowników w procesie tworzenia oraz funkcjonowania spółki europejskiej w Polsce, z uwzględnieniem ochrony indywidualnego stosunku pracy przedstawicieli strony pracowniczej, zbiorowych interesów pracowników oraz zabezpieczenia o charakterze prawnokarnym.

Słowa kluczowe: spółka europejska, zaangażowanie pracowników, informowanie, konsultacje, partycypacja, dialog społeczny, ochrona praw pracowników

\section{PROTECTION OF EMPLOYEES' RIGHTS IN TERMS OF INVOLVEMENT IN A EUROPEAN COMPANY BASED IN POLAND}

\section{Sum mary}

Employee involvement is one of the forms of implementing the broader concept of social dialogue. A European company is a supranational entity that operates in many European Union countries. The study analyzes protective mechanisms regarding employee involvement in the process of creating and operating a European company in Poland, including protection of the individual employment relationship of employees' representatives, collective employee interests and criminal-law guarantees.

Keywords: European company, employee involvement, information, consultation, participation, social dialogue, protection of employees' rights

\section{ЗАЩИТА ПРАВ РАБОТНИКОВ С ТОЧКИ ЗРЕНИЯ УЧАСТИЯ В ЕВРОПЕЙСКОЙ КОМПАНИИ С МЕСТОНАХОЖДЕНИЕМ В ПОЛЬШЕ}

Резюме

Вовлечённость сотрудников является одной из форм реализации более широкой концепции, которой является социальный диалог. Европейская компания является транснациональной организацией, которая осуществляет деятельность на территории многих государств-членов Европейского Союза. В данной статье анализируются защитные механизмы в области 
вовлечения сотрудников в процесс создания и функционирования европейской компании в Польше, принимая во внимание защиту индивидуальных трудовых отношений представителей работников, коллективных интересов работников, а также гарантии уголовно-правового характера.

Ключевые слова: Европейская компания, вовлеченность сотрудников, информация, консультации, участие, социальный диалог, защита прав работников 